\title{
Comparative study of the Politics, Social and Economic aspects related to biofuels in USA, People R China and Colombia
}

\author{
Guillermo Valencia Ochoa ${ }^{1}$, Luis Obregon Quiñones ${ }^{2}$, Martha Sofia Orjuela Abril ${ }^{3}$, \\ ${ }^{1}$ Efficient Energy Management Research Group, Universidad del Atlántico, \\ Carrera 30 Número 8 - 49, Puerto Colombia - Colombia \\ ${ }^{2}$ Research Group on Sustainable Chemical and Biochemical Processes, \\ Universidad del Atlántico, Carrera 30 No 8 - 49, Puerto Colombia, Colombia \\ ${ }^{3}$ Busines Science Faculty, Universidad Francisco de Paula Santander, Cucuta - Colombia \\ guillermoevalencia@mail.uniatlantico.edu.co
}

\begin{abstract}
The increase in $\mathrm{CO}_{2}$ production by the automotive sector has led to an increase in work towards new technologies that reduce their contribution to pollution, such as electric cars, hybrids and the use of fuels obtained from renewable sources or biofuels. This study has focused on the production of biofuels because it is the first renewable option for cleaner combustion because it significantly reduces carbon emissions. Because of this, the PES analysis looked at the reasons why this large difference occurs. The first review was of state regulations governing biofuel production in the three countries studied. The USA and People's R China have clear policies and very consistent goals accompanied by investments and tax extensions and these policies were compared with those implemented by Colombia to have a measure of how far this country is from the world powers in terms of biofuel production.
\end{abstract}

Keyword: Biofuel, $\mathrm{CO}_{2}$, Politics, Social, Economic.

\section{INTRODUCTION}

The automotive industry is one of the sectors that contributes the most to global pollution[1], which is why we have looked for ways to reduce the $\mathrm{CO} 2$ emitted by this industry. To this end, new technologies have been developed to reduce their contribution to pollution, such as electric cars, hybrids and the use of fuels obtained from renewable sources or biofuels. These are considered the most viable option to seek $\mathrm{CO}_{2}$ reduction in the automotive sector, despite the fact that the consumption of biodiesel and bioethanol only reached $4 \%$ of the fuel consumed in the sector[2], which shows that efforts must be increased to increase the production and consumption of biofuels.

The production of these fuels is based on different renewable sources. One of the raw materials investigated for this purpose is corn, although it has not been considered a viable biodiesel feedstock due to its high edible value and relatively high price, but some industrial corn processing co-products, such as corn germ and dry distilled soluble grains (DDGS), have potential for this application after extraction of corn distillery oil (CDO). For this reason, simpler, more effective and energy-saving technologies must be developed for the production of biodiesel, including more economical, efficient and reusable solid catalysts, continuous reactors with better mass transfer characteristics and the integration of reaction and separation phases in a single stage[3]. In addition, a closed process was proposed for the production of biofuel microalgae involving lipid extraction, anaerobic digestion and microalgae culture and $28.38 \%$ more energy was recovered as methane in LEM during the anaerobic digestion process. This would offset the cost of producing microalgae biofuels[4].In addition, the generation of biodiesel from recycled cooking oil was studied and the quality of the biodiesel was evaluated through various physicochemical properties and compared with the ASTM standards for biodiesel. Oleic acid, linoleic acid, palmitic acid and stearic acid were the main components of the biodiesel produced[5].

Bearing in mind that the variety of possibilities for the production of biofuel and that the production of biofuel has become more attractive due to its enormous reduction in greenhouse gas emissions. Although theproduction of biodiesel can affect water resources, soil and biodiversity, an appropriate policy can help to produce sustainable biodiesel in a natural way[6].

The contribution of this work is focused on the comparison of the policies that drive the production and development of biofuels in economic powers such as the USA and People R China and how these policies have affected economically and socially compared to what Colombia has done to achieve the objectives of reducing emissions and improving the rational use of resources. 


\section{METHODOLOGY}

Following is a brief description of the study carried out, which will detail the production process of biofuel, raw materials used and explain the method by which the comparative analysis of the nations involved in this research was made.

\subsection{Review of concepts}

Biofuels are a replacement for conventional fuels, which contain components derived from living organisms or metabolic waste and from which biodiesel is obtained. This fuel is the first renewable option for cleaner combustion because it significantly reduces carbon emissions[7]. A series of steps described in figure 1 are carried out for production. It begins with the extraction of the oil from the raw material used (A) to obtain the crude vegetable oil (B), then the first separation of fat (C) is carried out, resulting in the refined vegetable oil (D), followed by the second separation of fat (E) and purification (F) to finally obtain the biofuel (G).

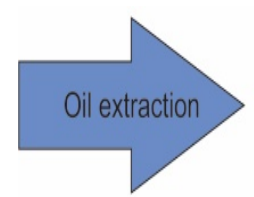

(A)

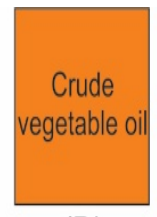

(B)

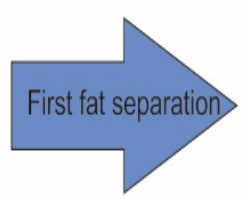

(C)

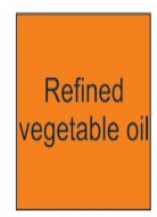

(D)

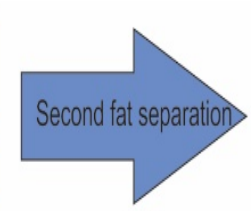

(E)

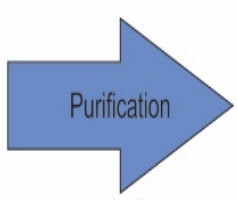

$(\mathrm{F})$

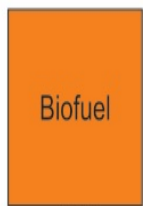

(G)

Figure 1. Biofuel production process

\subsection{Types of biofuels and feedstocks}

The product of this process is used as a pure diesel replacement in engines that use this fuel, but it is also used in combination with diesel at different concentrations such as B20 (20\% biodiesel, 80\% petroleum diesel), B5 (5\% biodiesel, 95\% petroleum diesel) and B2 (2\% biodiesel, 98\% petroleum diesel) being the most common pure (B100) in the United States. And the most common products used for biofuel production are vegetable oils such as soybean oil, cottonseed oil, canola oil, corn oil, recycled cooking fats or oils, and animal fats such as beef tallow, lard, and a variety of combinations of these raw materials. The cooking oils are recycled and most of them are of vegetable origin, but they can also contain animal fats[8].

\subsection{PES analisys}

Three important aspects were taken into account in this study. These were the political, economic and social aspects. With the first one, he sought to know the standards that helped the growth of production and the advancement of biofuel technologies. On the other hand, in economic terms, the investments of the states studied were known. And finally, the social aspect, which showed the benefits that the implementation and use of the policies that govern biofuels brought to the people.

In addition, an analysis of the growth performance of the research was conducted to identify whether the investment policies of the countries were reflected in research results. For this purpose, metadata was downloaded from the Web of Science, Biofuel was used as the search phrase, and after obtaining the metadata, it was processed by HitCite. In this way, the growth of research on this subject was obtained.

\section{RESULTS AND DISCUSSION}

Research on biodiesel since 2007 has shown a considerable and constant increase from just over 300 studies in 2007 to over 800 in 2015, which is the peak of research. This represents an increase of approximately $166 \%$ between these two years, as can be seen in theFigure 2 . 


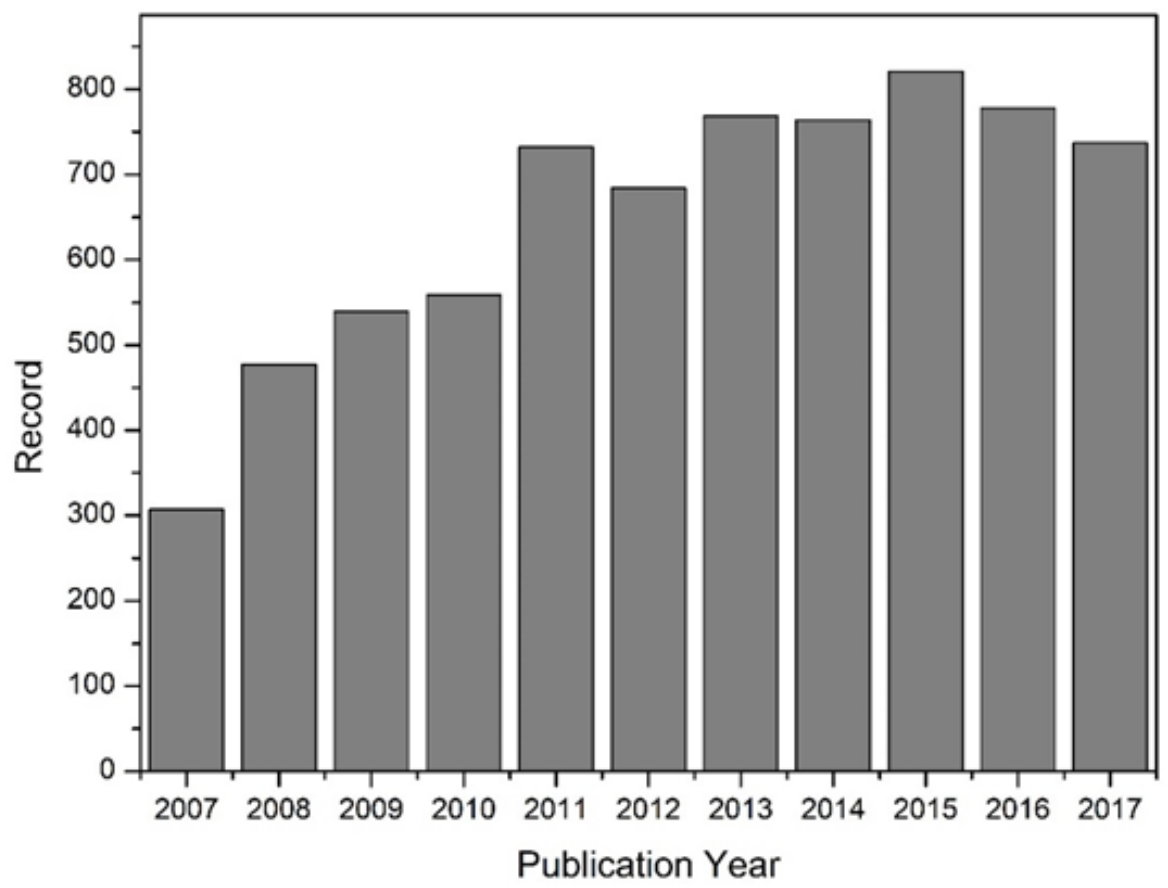

Figure 2. Number of publications per year

Similarly, the annual contribution of the two countries with the greatest number of research projects in the last 11 years, which were the USA and People's Republic of China, was analyzed and a comparison was made of the annual publications of these two countries with those of Colombia during this period of time. Figure 3 shows how the USA has always been far ahead of the publications made by People R China and the difference with Colombia is very great. This country reached its highest publication point with a number of 5 publications being very far from the U.S. bottom line and equalling China only in the value of its first year in this study.

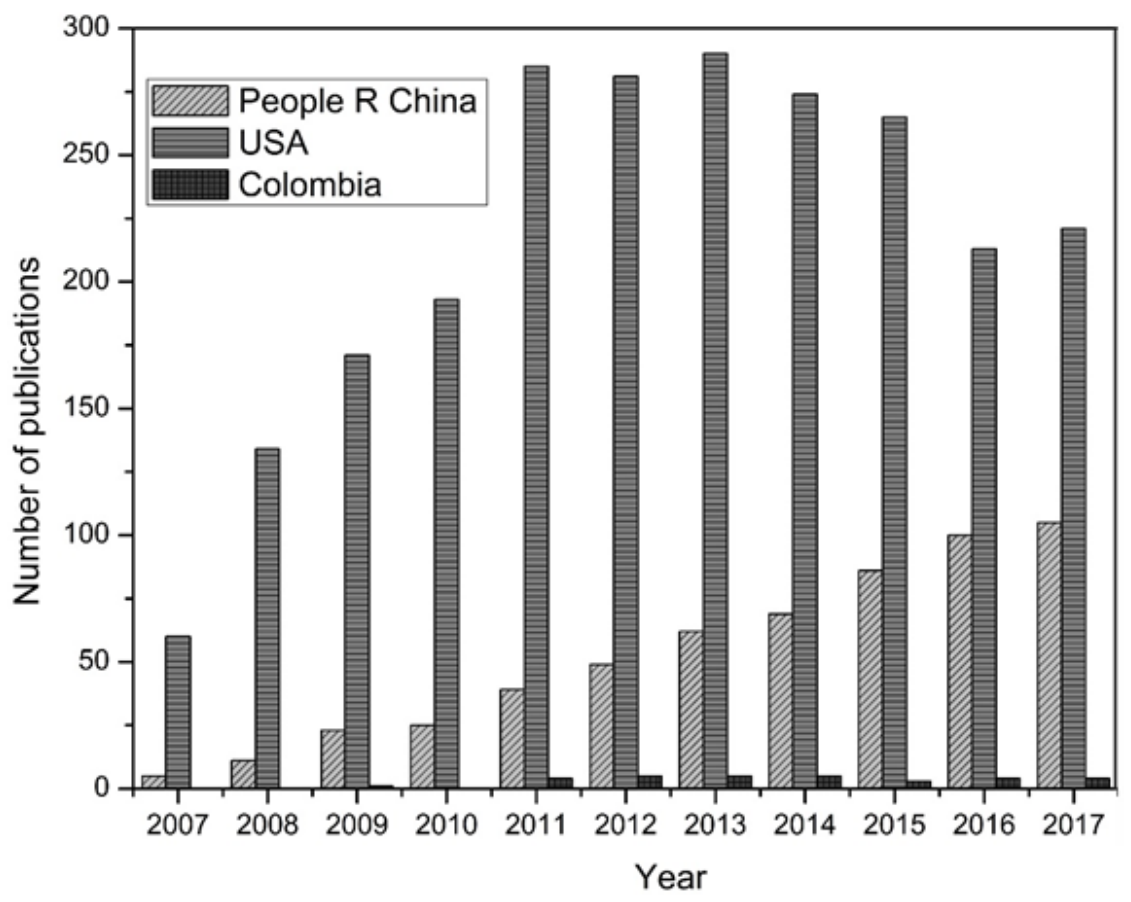

Figure 3. Publications by country 
Because of this, the PES analysis looked for the reasons for this large difference. The first review was of state regulations governing biofuel production in the three countries studied. The USA and People's R China have clear and consistent policies and goals, accompanied by investments and tax extensions described in Table 1, which led to an increase in research in these two countries. On the other hand, Colombia does not have policies focused on biofuel production and almost no investment in this technology, as can be seen in Table 1, which has not encouraged research in this field and, thanks to this, the social results are nil, contrary to what is observed in People R China and the USA, which have shown various types of benefits such as improvements in the environment and an increase in the employment rate of their citizens. But there are also negative aspects, such as the increase in food prices due to the increase in demand for these products.

Table 1. PES analisys

\begin{tabular}{|c|c|c|c|}
\hline Criteria & USA & People R China & Colombia \\
\hline Policies & $\begin{array}{l}\text { In 2007, the law on energy } \\
\text { independence and security was } \\
\text { established, which established the } \\
\text { proportion of renewable raw materials in } \\
\text { biofuels[9]. The objective is to increase } \\
140 \text { million } m^{3} \text { by } 2022 \text {, which means an } \\
\text { increase of } 61 \text { million } m^{3} \text { compared to } \\
\text { what was established in the year of } \\
\text { publication of the law. This biofuel must } \\
\text { also be derived from sources other than } \\
\text { corn starch. On the other hand, the } \\
\text { development of biofuels requires studies } \\
\text { on the use of algae as feedstock for } \\
\text { biofuel[9].In addition, a Renewable Fuel } \\
\text { Standard was set which categorizes } \\
\text { renewable fuels into conventional and } \\
\text { advanced biofuels. }\end{array}$ & $\begin{array}{l}\text { In } 2009 \text {, a plan was proposed } \\
\text { to promote the use of } \\
\text { biodiesel in Hainan province, } \\
\text { which promotes the use of B5 } \\
\text { fuel, the same mandate } \\
\text { prohibiting the sale of pure } \\
\text { diesel. In 2010, the excise } \\
\text { duty on biodiesel production } \\
\text { from used oils will be } \\
\text { extended[10]. In 2010, the } \\
\text { Chinese government created } \\
22 \text { research centers that seek } \\
\text { to promote advances in the } \\
\text { energy sector, among them } \\
\text { the national center for energy } \\
\text { R\&D for biofuels [11]. }\end{array}$ & $\begin{array}{l}\text { Colombia's policies regarding the } \\
\text { production and use of biofuels are } \\
\text { not very clear, and the government } \\
\text { has not bothered to specify specific } \\
\text { measures for this fuel technology. } \\
\text { In 1994, it issued Law } 142 \text { in which } \\
\text { it obliged companies to implement } \\
\text { rational energy use programs for all } \\
\text { processes[12]. In the same year, } \\
\text { Law } 143 \text { designated the UPME to } \\
\text { Establish as a priority an energy } \\
\text { saving and optimization } \\
\text { program[[13]. In 2004, the } \\
\text { characteristics that biofuel must } \\
\text { meet to be considered as such were } \\
\text { clarified[14]. }\end{array}$ \\
\hline $\begin{array}{l}\text { Economic } \\
\text { aspect }\end{array}$ & $\begin{array}{l}\text { The production of ethanol for biodiesel } \\
\text { in } 2017 \text { reached } 59 \text { million } m^{3} \text { and } \\
\text { provided employment for more than } 71 \\
\text { thousand Americans. Similarly, industry } \\
\text { supported more than } 280,000 \\
\text { investments that generated jobs in all } \\
\text { sectors of the economy and contributed } \\
45 \text { billion dollars to GDP and spent } \\
\text { more than } 30 \text { billion dollars on raw } \\
\text { materials, inputs and other goods [15]. } \\
\text { In addition, biofuel production generated } \\
\text { a } \$ 14.1 \text { billion increase in the value of } \\
\text { the agricultural sector. }\end{array}$ & $\begin{array}{l}\text { China's tax policy has been to } \\
\text { reimburse value added tax } \\
\text { (VAT) to ethanol producers. } \\
\text { This incentive was phased out } \\
\text { by reimbursing } 80 \% \text { in } 2011 \text {, } \\
60 \% \text { in } 2012,40 \% \text { in } 2013 \\
\text { and } 20 \% \text { in } 2014 \text {, and in the } \\
\text { following years there was no } \\
\text { reimbursement. As for } \\
\text { biodiesel, the production of } \\
\text { biodiesel is exempted[10]. }\end{array}$ & $\begin{array}{l}\text { In Decree } 2532 \text { of 2001, the } \\
\text { Ministry of the Environment, } \\
\text { Housing and Territorial } \\
\text { Development of the Colombian } \\
\text { government established the form } \\
\text { and requirements for obtaining tax } \\
\text { extensions on national and imported } \\
\text { equipment and elements used for } \\
\text { the construction, installation, } \\
\text { assembly and operation of control } \\
\text { and monitoring systems necessary } \\
\text { for compliance with environmental } \\
\text { provisions, regulations and } \\
\text { standards[16] }\end{array}$ \\
\hline Society & $\begin{array}{l}\text { The biodiesel industry has generated an } \\
\text { increase in female employment due to } \\
\text { the fact that } 30 \% \text { of its employees are of } \\
\text { this type, with a value of more than } 25 \% \\
\text { of female jobs in the oil-based fuel } \\
\text { industry. On the other hand, } 23 \% \text { of } \\
\text { employees are } 55 \text { years of age or older, } \\
8 \% \text { are trade unionists and } 19 \% \text { are } \\
\text { military veterans. These percentages are } \\
\text { higher than those presented by the oil- } \\
\text { based fuel industry except for trade } \\
\text { unionists, where they are } 12 \%[15] \text {. This } \\
\text { demonstrates the social benefits } \\
\text { generated by the biodiesel industry. }\end{array}$ & $\begin{array}{l}\text { About } 14 \% \text { of the Asian } \\
\text { population has low food } \\
\text { security, and } 560 \text { million } \\
\text { people in Asia have this } \\
\text { problem[17]. Bearing this in } \\
\text { mind, and that resources such } \\
\text { as land, water, labour and } \\
\text { food crops are needed for } \\
\text { biofuel production[18].This } \\
\text { can have a negative impact } \\
\text { due to the increase in demand, } \\
\text { which can cause food prices } \\
\text { to skyrocket. }\end{array}$ & $\begin{array}{l}\text { On the social front, the results have } \\
\text { not been very significant due to the } \\
\text { regulations presented by the } \\
\text { government, which were not very } \\
\text { concrete and did not generate the } \\
\text { necessary momentum to advance } \\
\text { biofuel research. The Colombian } \\
\text { government is focused on oil } \\
\text { exploitation, which has had a } \\
\text { negative impact on the Guajira's } \\
\text { watersheds[19]. }\end{array}$ \\
\hline
\end{tabular}

\section{CONCLUSION}

Finally, we can conclude that Colombia as a developing country is far from making a significant contribution to the production of biofuels due to its null policies. In comparison with the serious and committed approach of the great world economic powers that have provided economic incentives to the productive sectors, this has been reflected in very positive social results. On the contrary, in Colombia, despite being a country very rich in resources, decisions are leading to environmental damage to water resources that negatively affect its population. 


\section{REFERENCES}

[1] PriceWaterhouseCoopers, "The automotive industry and climate change: Framework and Dynamics of the CO2 Revolution," vol. 2, pp. 1-126, 2007.

[2] Y.-K. Oh, K.-R. Hwang, C. Kim, J. R. Kim, and J.-S. Lee, "Recent developments and key barriers to advanced biofuels: A short review," Bioresource Technology, vol. 257, pp. 320-333, Jun. 2018.

[3] V. B. Veljković et al., "Biodiesel production from corn oil: A review," Renewable and Sustainable Energy Reviews, vol. 91, pp. 531548, Aug. 2018.

[4] L. Yang et al., "Nutrients recycling and energy evaluation in a closed microalgal biofuel production system," Algal Research, vol. 33 , pp. 399-405, Jul. 2018

[5] Sahar et al., "Biodiesel production from waste cooking oil: An efficient technique to convert waste into biodiesel," Sustainable Cities and Society, vol. 41, pp. 220-226, 2018.

[6] M. M. Hasan and M. M. Rahman, "Performance and emission characteristics of biodiesel-diesel blend and environmental and economic impacts of biodiesel production: A review,” Renewable and Sustainable Energy Reviews, vol. 74, pp. 938-948, Jul. 2017.

[7] laboratorio nacional del Laboratorio Nacional de Energía Renovable (NREL, por sus siglas en inglés), O. de Departamento de Energía de los Estados Unidos, and Eficiencia Energética y Energía Renovable., "Biodiesel Basics (Spanish Version)," Energy Efficiency \& Renewable Energy, p. 2, 2015.

[8] T. L. Alleman, R. L. McCormick, E. D. Christensen, G. Fioroni, K. Moriarty, and J. Yanowitz, Biodiesel Handling and Use Guide, no. November. 2016.

[9] U.S. Congress, "Energy independence and security act of 2007," Public Law, pp. 1-311, 2007.

[10] H. Hao et al., "Biofuel for vehicle use in China: Current status, future potential and policy implications," Renewable and Sustainable Energy Reviews, vol. 82, pp. 645-653, Feb. 2018.

[11] R. R. Scott and J. Jiang, "Global agricultural information network report number 11039," Peoples Republic of China—2011 Annual Biofuels Report, pp. 1-12, 2011.

[12] Ley 142, "Ley 142 de 1994," Diario Oficial, vol. 1994, no. 41.433, p. 597, 1994.

[13] Ministerio de Minas y Energía, "Ley 143 de 1994 - Ley Eléctrica," Diario Oficial, vol. 1994, no. 41434, p. 347, 2002.

[14] C. de la republica de Colombia, "Ley 939 de 2004," vol. 2004, no. diciembre 31, p. 3, 2004.

[15] T. Wilson, R. Baker, M. Ricketts, S. Roe, C. Wilson, and N. Koehler, "2016 Ethanol Industry Outlook," Renewable Fuels Association, pp. 1-31, 2016.

[16] M. DE AMBIENTE, "Ministerio de ambiente, vivienda y desarrollo territorial," Resolucion N 978, vol. 2, pp. 1-9, 2007.

[17] FAO, The State of Food Insecurity in the World 2012. 2012.

[18] a Faaij, "Bioenergy and global food security. The BEFS Analytical Framework," Change, no. ISSN 2071-0992, p. $92,2008$.

[19] J. A. Torres, "Sumario."

\section{AUTHOR PROFILE}

Luis Obregon Quiñones Chemical Engineer graduated from the Universidad del Atlántico in 1998. Magister (2003), Doctor (2009) and Postdoctor in Chemical Engineering from the University of Puerto Rico, Mayagüez University Campus(2010). Among its areas of activity are pharmaceutical process engineering, transport phenomena, and fluid mechanics. He is currently an associate professor of the Chemical Engineering program, leader of the Sustainable Chemical and Biochemical Processes research group and leader of the Accreditation process of the Chemical Engineering program at the Universidad del Atlántico.

Martha Sofía Orjuela Abril born in Cucuta, Colombia. Is a full-time professor at the Universidad Francisco de Paula Santander. Received a degree in Industrial Engineering from Universidad Libre de Colombia in 2003. Master in Business Administration with a specialization in Project Management from Universidad del Mar in 2014.

Guillermo Valencia Ochoa born in Barranquilla, Colombia. Is a full-time professor at the Universidad del Atlántico. Received a degree in Mechanical Engineering from Universidad del Norte, located in Barranquilla, Colombia in 2005. Master in Mechanical Engineering from Universidad del Norte, Barranquilla, Colombia in 2008.Ph. D in Engineering from the Universidad PontificiaBolivariana, Medellin, Colombia in 2014. He is an assistant professor of the Mechanical Engineering Program, Specialization in Energy Efficient Management and Master in Energy Management at Universidad del Atlántico. 